\title{
Interventional procedures for biliary drainage with bilioplasty in paediatric patients: dosimetric aspects
}

\section{Procedure interventistiche di drenaggio biliare con bilioplastica su pazienti pediatrici: aspetti dosimetrici}

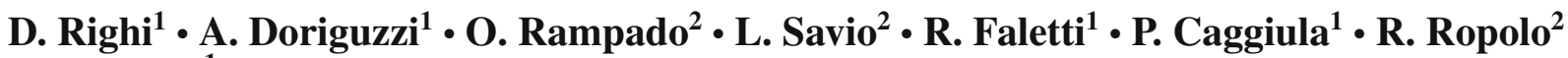 \\ G. Gandini ${ }^{1}$
}

\begin{abstract}
${ }^{1}$ Radiologia Diagnostica Universitaria, Ospedale San Giovanni Battista, Via Genova 3, 10126 Torino, Italy
${ }^{2}$ Struttura Complessa Fisica Sanitaria I, Ospedale San Giovanni Battista, Corso Bramante 88/90, 10126 Torino, Italy

Correspondence to: O. Rampado, Tel.: +39-011-6335373, Fax: +39-011-6634547, email: orampado@molinette.piemonte.it
\end{abstract}

Received: 13 March 2007 / Accepted: 11 June 2007 / Published online: 25 April 2008

(C) Springer-Verlag 2008

\begin{abstract}
Purpose. This study was undertaken to evaluate patient dose in paediatric liver transplant recipients treated by percutaneous biliary drainage and bilioplasty procedures.

Materials and methods. Effective dose rates and entrance skin-dose (ESD) rates per minute of fluoroscopy were measured by using a plexiglas phantom (thickness $10 \mathrm{~cm}$ ) simulating the patient and by varying the exposure parameters (type of pulsed fluoroscopy, image intensifier diameter, presence of diaphragms) to identify the technique delivering the lowest patient dose. In vivo measurements were performed during three interventional procedures.

Results. The effective dose rate proved to be lowest for a particular type of pulsed fluoroscopy, with maximum magnification and with field-limiting diaphragms. The in vivo measurements showed a maximum ESD value of around $50 \mathrm{mGy}$ (the threshold for transient erythema is $2,000 \mathrm{mGy}$, ICRP 60 ). The effective dose values were in the range of $0.9-1.5 \mathrm{mSv}$.

Conclusions. We established exposure parameters providing the desired image quality with the lowest dose for the equipment used and for a specific type of interventional procedure. The measured ESD values allow us to exclude the risk of deterministic effects on the skin. The effective dose values and considerations regarding the likelihood of radiation-induced cancer led to the conclusion that the radiological risk for the patient is largely justified by the benefits of these kinds of procedure.
\end{abstract}

Riassunto

Obiettivo. Valutazione della dose al paziente per procedure di drenaggio biliare e bilioplastica percutanea in pazienti pediatrici trapiantati di fegato.

Materiali e metodi. Sono stati misurati i ratei di dose efficace e di dose superficiale in ingresso (ESD) per minuto di scopia, simulando la presenza del paziente con fantoccio in plexiglass di $10 \mathrm{~cm}$ di spessore e variando $i$ parametri di esposizione (tipo di scopia pulsata, diametro $I B$, presenza di diaframmi) al fine di individuare le modalità che consentono di minimizzare la dose. Nel corso di tre procedure sono state effettuate misure in vivo. Risultati. I valori di rateo di dose efficace sono risultati minimi per un particolare tipo di scopia pulsata, per il massimo ingrandimento e in presenza di diaframmatura. I risultati delle misure in vivo mostrano un valore massimo di ESD di circa $50 \mathrm{mGy}$ (valore soglia per eritema temporaneo $2000 \mathrm{mGy}$, ICRP 60). I valori di dose efficace sono compresi tra 0,9 e $1,5 \mathrm{mSv}$.

Conclusioni. Sono stati stabiliti i parametri di esposizione che consentono di ottenere la qualità di immagine desiderata con la minima dose, per l'apparecchiatura utilizzata e per questa tipologia di procedure. I valori di ESD misurati permettono di escludere il rischio di insorgenza di danni deterministici alla cute. I valori di dose efficace e le considerazioni conseguenti relative alla probabilità di induzione di tumori letali consentono di affermare che i benefici associati a questo tipo di procedure giustificano ampiamente l'esposizione del paziente al rischio radiologico associato. 
Keywords Paediatric liver transplantation · Dosimetry · Percutaneous biliary drainage $\cdot$ Bilioplasty
Parole chiave Trapianto di fegato pediatrico $\cdot$ Dosimetria . Drenaggio biliare percutaneo $\cdot$ Bilioplastica

\section{Introduction}

Biliary complications in liver transplantation are the most frequent cause of postoperative morbidity, with incidence rates of 30\%-60\%. Mostly strictures or fistulae, these complications appear more frequently within the first 3 months after surgery (early complications) and rarely after the first year (late complications). Anastomotic strictures are also a frequent complication of paediatric liver transplantation. They may appear within the first few weeks as a result of technical errors or ischemic, immunological or infectious causes, or after several months, usually as a result of relapse or chronic evolution of early complications. Among minor biliary complications, the most common $(6 \%-29 \%)$ is the formation of debris, stones and biliary sludge of varying severity $[1,2]$.

Treatment for biliary complications, such as strictures of the biliodigestive anastomosis or lithiasis, by percutaneous biliary drainage and bilioplasty or by lithotripsy is successful in most cases, allowing resolution without surgical revision or repeat transplantation $[3,4]$. The use of interventional procedures in children who have undergone orthotopic liver transplantation (OLT) allows a safe and minimally invasive approach to many postoperative complications and spares the patients further surgical procedures [5, 6]. Percutaneous biliary drainage, as well as permitting the performance of direct cholangiography, allows drainage and saline lavage of the bile duct and is the first step in subsequent treatment with bilioplasty and lithotripsy.

Percutaneous treatment of biliary complications is also the initial approach in children who have undergone OLT $[7,8]$. However, reduced patient cooperation, long fluoroscopy times and the need for repeat procedures demand that special attention be paid to radiation protection issues, in consideration of the higher sensitivity to ionising radiation and the longer life expectancy of paediatric patients. The radiological risk associated with these procedures may be deterministic, in particular with regard to possible skin injury, or it may be stochastic, referring to the increased likelihood of cancer. The dose received by the patient should thus be assessed to estimate the extent of risk associated with radiation exposure. The dosimetric quantity used to evaluate deterministic effects to the skin is the entrance skin dose (ESD), whereas stochastic risk can be measured by estimating the effective dose. In addition to these, the dose-area product (DAP) is an indicator of the total patient dose and can serve as a valuable tool for comparison.

\section{Introduzione}

Le complicanze biliari nel trapianto di fegato rappresentano la più frequente causa di morbilità post chirurgica, con percentuali del 30\%-60\%; si tratta principalmente di stenosi o fistole, ed insorgono più frequentemente nei primi tre mesi (complicanze precoci), più di rado dopo il primo anno (complicanze tardive). Le stenosi anastomotiche rappresentano anche nel trapianto pediatrico le complicanze più frequenti; si manifestano entro le prime settimane per causa ischemica, immunologica, infettiva o errore tecnico oppure dopo molti mesi dal trapianto solitamente per recidiva o cronizzazione di complicanze precoci. Tra le complicanze biliari minori la più frequente (dal 6\% al 29\%) è rappresentata dalla formazione di detriti, calcoli e sludge biliare di varia entità sino ai quadri più gravi $[1,2]$.

Il trattamento delle complicanze biliari post trapianto epatico, quali la stenosi dell'anastomosi bilio-digestiva o la litiasi, mediante procedure di drenaggio biliare percutaneo transepatico associato a bilioplastica o litotripsia percutanea consente di risolvere il maggior numero di complicanze di questo tipo senza ricorrere alla revisione chirurgica o al ritrapianto [3, 4]. Il ricorso a procedure interventistiche in pazienti pediatrici sottoposti a trapianto di fegato (OLT, Orthotopic Liver Transplant) consente di affrontare in modo sicuro e poco invasivo le molte complicanze post-chirurgiche, evitando ai pazienti ulteriori interventi chirurgici [5, 6]. Il drenaggio biliare percutaneo, oltre a consentire l'esecuzione di un colangiogramma diretto, consente il drenaggio della bile, l'esecuzione di lavaggi con soluzione fisiologica ed è il primo tempo per il successivo trattamento con bilioplastica e litotripsia.

Il trattamento percutaneo delle complicanze biliari rappresenta attualmente il primo approccio anche nel paziente pediatrico sottoposto ad OLT [7, 8]; tuttavia la scarsa collaborazione dei pazienti, i lunghi tempi di fluoroscopia e la necessità di trattamenti spesso ripetuti nel tempo, impongono di porre estrema attenzione agli aspetti radioprotezionistici tenendo conto della maggiore suscettibilità alle radiazioni ionizzanti e la maggiore spettanza di vita del paziente pediatrico. I rischi di natura radiologica associati a tali procedure possono essere di carattere deterministico, in particolare per la possibilità di danni alla cute, e stocastico, con l'aumento della probabilità di insorgenza di neoplasie. Risulta quindi utile una valutazione della dose ricevuta dal paziente per stimare la severità del rischio associato all'esposizione. La grandezza dosimetrica che consente di valutare il raggiungimento di effetti deterministici alla cute 
The purpose of this study was to evaluate the dose to the patient, through measurements and calculations, of the various exposure conditions during a procedure to obtain information for dose optimisation. In three cases, we performed in vivo measurements to evaluate the effective dose to the patient and present some considerations about the related risks.

\section{Materials and methods}

Between October 1999 and November 2006, eight children with post-OLT biliary complications underwent interventional biliary drainage with bilioplasty at our institution. All procedures were carried out with a Philips Multidiagnost 3 (Philips Medical Systems, Best, the Netherlands). In vivo measurements of patient dose were obtained during procedures on three patients (two girls and one boy; ages 14 months, 3 years and 5 months, and 3 years, respectively; mean age 30.3 months) who presented with tight stenosis of the biliodigestive anastomosis after OLT. In addition, measurements were obtained by simulating the operating conditions with a 10-cm-thick Plexiglas phantom.

Interventional procedure

When placing the transhepatic biliary drain and performing bilioplasty with balloon catheters in children, special care must be taken to minimise exposure by limiting the use of ionising radiation as far as possible and employing ultrasonography. Furthermore, as an additional precaution, lead screens are placed between the bed and the back (the X-ray source is placed under the patient) to shield all parts of the body (chest, neck, lower abdomen) excluding the area of interest (upper abdomen).

In our procedures, biliary puncture with a Chiba needle and insertion of the guidewire and introducer were carried out exclusively under sonographic guidance (Fig. 1a). For cholangiography and evaluation of the morphology and location of the stricture, a brief run of pulsed fluoroscopy at two pulses per second, with maximum magnification and maximum field limiting, was employed to confine exposure to the area of interest, with reduced kilovolt and milliampere settings $(68 \mathrm{kV}$ and $1.5 \mathrm{~mA})$. The stricture was then crossed with a hydrophilic guidewire using brief fluoroscopy runs for the shortest time possible (Fig. 1b). The duration of this phase is crucial, as strictures that are difficult to cross may require longer fluoroscopy times and increase patient exposure.

A balloon catheter was then advanced on the metal guidewire under sonographic guidance, and fluoroscopy was used only to monitor dilatation of the balloon: a 6-mm balloon catheter in one case and an 8-mm cutting balloon in the other (Fig. 2). After cholangiography with a brief fluoroscopy run with reduced parameters to confirm the out- è la dose d'ingresso superficiale (ESD, entrance skin dose) mentre il rischio stocastico può essere quantificato per mezzo di una stima della dose efficace. Accanto a queste grandezze è inoltre utile la valutazione del prodotto dose per area (DAP) come indicatore di dose totale al paziente e strumento di confronto.

Scopo del lavoro è stato quello di valutare la dose al paziente, mediante misure e calcolo, per le diverse condizioni di esposizione che si verificano durante una procedura, in modo da ottenere informazioni utili per l'ottimizzazione della dose. In tre casi sono state inoltre effettuate delle misure in vivo che hanno permesso di valutare la dose efficace al paziente e di effettuare delle considerazioni sul rischio correlato.

\section{Materiali e metodi}

Nel periodo tra ottobre 1999 e novembre 2006 presso l'Istituto Universitario di Radiodiagnostica dell'Ospedale Molinette (Torino) sono state eseguite procedure interventistiche di drenaggio biliare con bilioplastica su 8 pazienti pediatrici con complicanze biliari post OLT. L'apparecchio utilizzato per l'esecuzione delle procedure è stato un Philips Multidiagnost 3 (Philips Medical Systems, Best, Olanda). Sono state effettuate misure di dose al paziente in vivo nel corso di procedure eseguite su 3 pazienti pediatrici (età di 14 mesi, 3 anni e 5 mesi e 3 anni;età media 30,3 mesi; 2 femmine e 1 maschio) che presentavano stenosi serrata dell'anastomosi bilio-digestiva dopo trapianto di fegato. Inoltre sono state effettuate misure simulando le condizioni operative delle procedure, con un fantoccio in plexiglass di $10 \mathrm{~cm}$ di spessore.

Procedura interventistica

Durante la procedura interventistica di posizionamento di drenaggio biliare transepatico e la successiva bilioplastica mediante cateteri a palloncino, in tali pazienti deve essere posta particolare attenzione nel ridurre al minimo l'esposizione, limitando il più possibile l'utilizzo di radiazioni ionizzanti ed avvalendosi dell'ausilio dell'ecotomografia. Inoltre ad ulteriore protezione dei piccoli pazienti vengono posizionate delle schermature piombifere tra il lettino ed il dorso (la sorgente radiogena si colloca sotto il paziente) in modo da schermare tutte le parti corporee (torace, collo, addome inferiore) eccetto la regione di lavoro (addome superiore).

Nelle nostre procedure la puntura biliare con ago di Chiba e l'introduzione del filo guida e dell'introduttore è stata eseguita con esclusivo controllo ecotomografico (Fig. la). Per il controllo colangiografico e la valutazione della morfologia e della localizzazione della stenosi, è stato uti- 

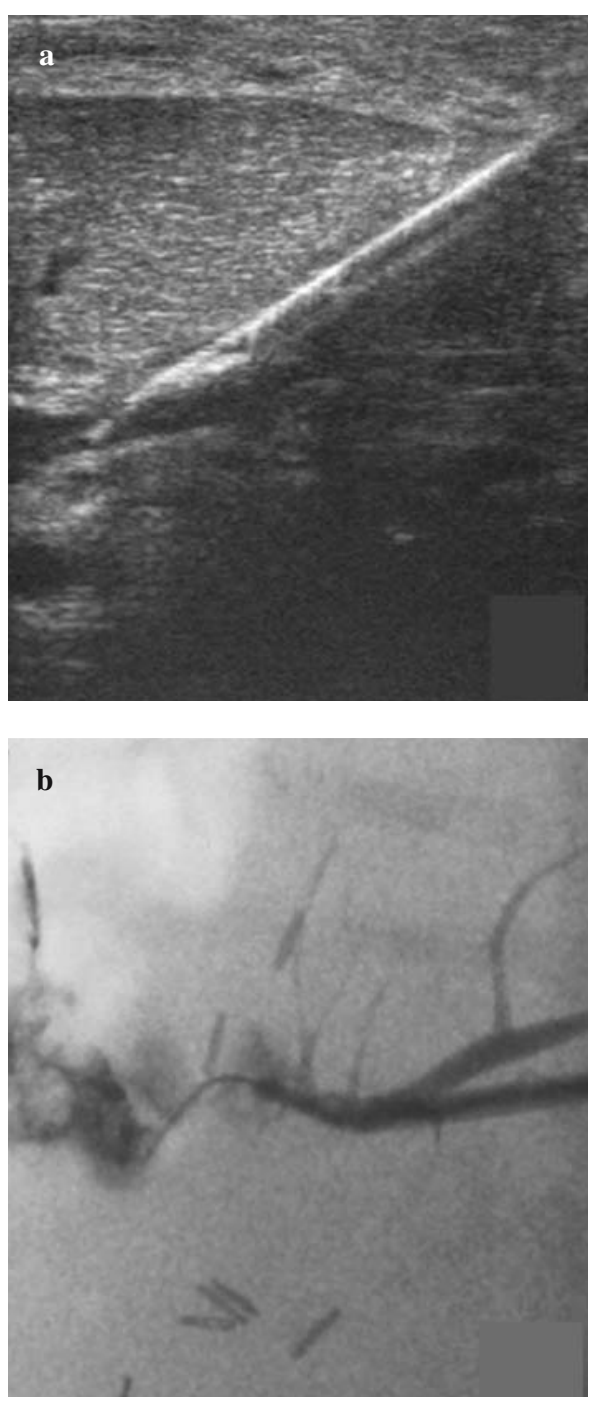

Fig. 1a Biliary puncture under sonographic guidance with Chiba needle (21 gauge). b After positioning the coaxial system, stenosis of the biliodigestive anastomosis is crossed with a 0.035 -in. hydrophilic guidewire.

Fig. 1a Puntura biliare sotto guida ecografica con ago di Chiba da 21 G. $\boldsymbol{b}$ Previo posizionamento di sistema coassiale si valica la stenosi dell'anastomosi biliodigestiva con guida idrofilica da 0,035".

come, the procedure was completed under sonographic guidance. In one case, the drainage catheter and guidewire were removed and the percutaneous tract embolised with a Gianturco coil (Fig. 3). In the other two cases, sonographic guidance was used to place an internal or internal-external biliary drain followed by a brief fluoroscopy run at the end of the manoeuvre.

Complete technical success was achieved in all procedures, and there were no periprocedural complications, which allowed mean fluoroscopy time to be reduced to 3.7 $\min$.
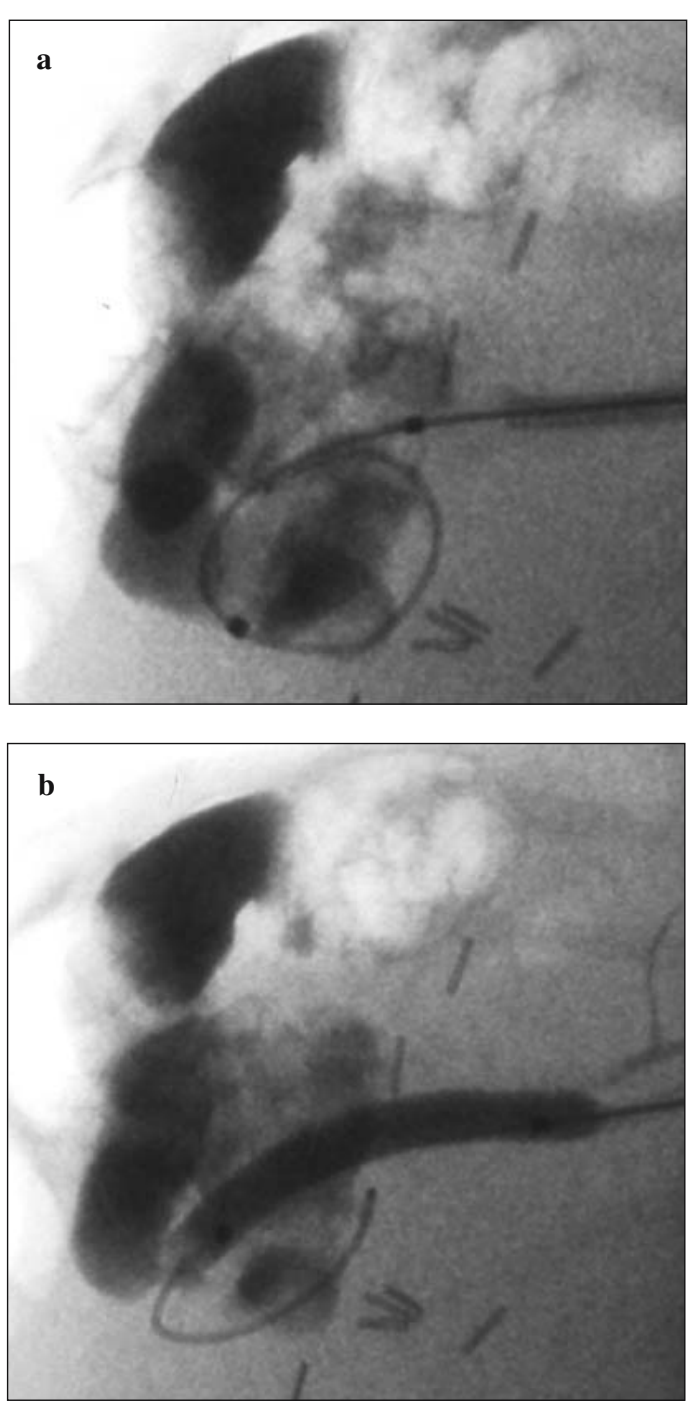

Fig. 2a,b Bilioplasty of the biliodigestive anastomosis with a 4-mm-diameter angioplasty balloon.

Fig. 2a,b Bilioplastica dell'anastomosi biliodigestiva con palloncino da angioplastica di $4 \mathrm{~mm}$ di diametro.

lizzato un rapido flash di scopia pulsata a 2 impulsi/s, al massimo ingrandimento, con massima diaframmatura, per limitare l'esposizione al distretto d'interesse, a voltaggio e amperaggio ridotti (68 $\mathrm{kV}$ e 1,5 $\mathrm{mA}$ ). Mediante filo guida idrofilico si valica quindi la stenosi, avvalendosi della scopia per il minor tempo possibile con rapidi flash (Fig. Ib). La durata di questa fase è di fondamentale importanza, in quanto in presenza di stenosi difficilmente valicabili tale durata può allungarsi con aumento dell'esposizione del paziente.

Viene quindi fatto avanzare il catetere a palloncino sulla 

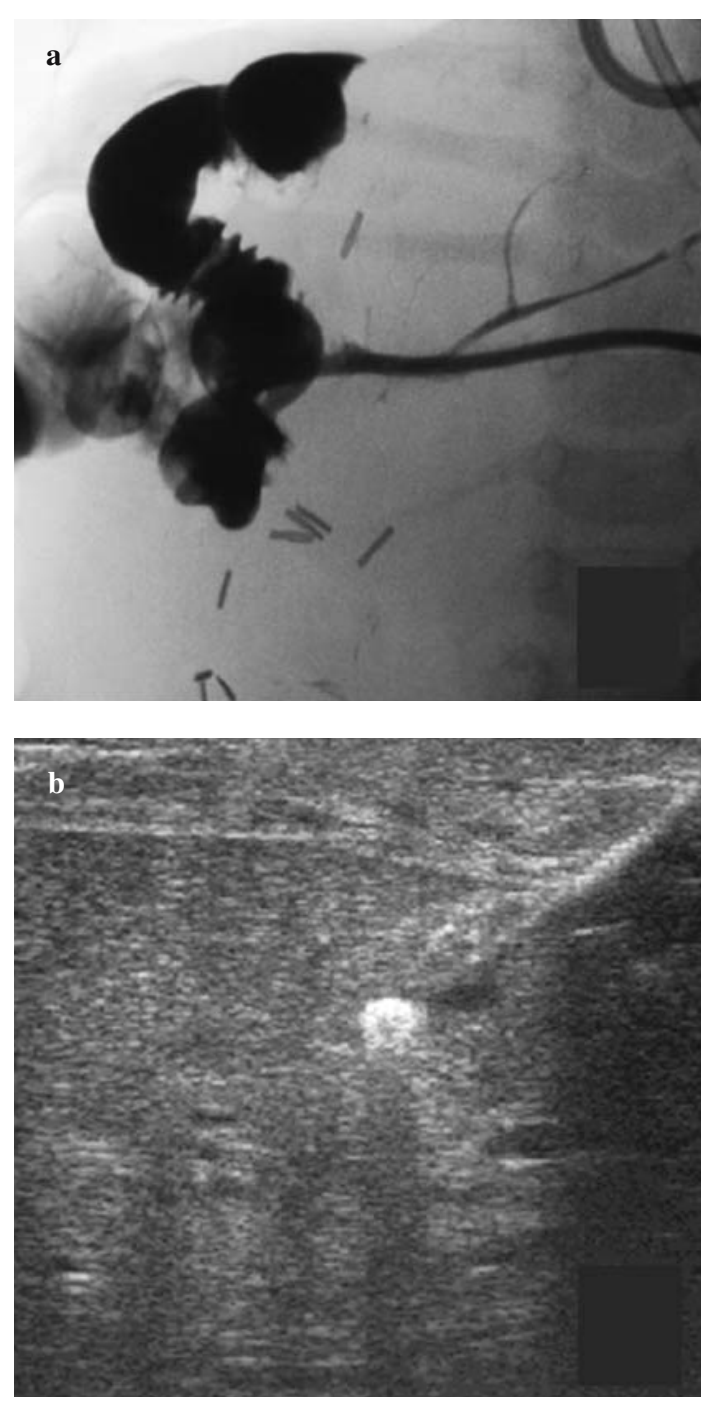

Fig. 3a Postprocedural cholangiography demonstrates the success of percutaneous bilioplasty, with regular flow of bile into the jejunal loop. b After coil embolisation under sonographic guidance, the percutaneous access is removed.

Fig. 3a La colangiografia al termine della procedura dimostra il buon esito della bilioplastica percutanea con regolare deflusso di bile opaca nell'ansa digiunale. $\boldsymbol{b}$ Previa embolizzazione del tramite sotto guida ecografica con spirale metallica si rimuove l'accesso percutaneo.

Dosimetric measurements

In addition to the measurements normally recorded for our quality-assurance programme, specific dosimetric measurements were performed to characterise the device used and produce a reliable dose estimate. To assess the impact of operator-dependent exposure parameters (fluoroscopy mode, image intensifier diameter and field-limiting diaphragm), measurements were performed by simulating the operating conditions, with a $10-\mathrm{cm}$-thick Plexiglas phantom, focus-patient distance $75 \mathrm{~cm}$, focus-image intensifier distance $120 \mathrm{~cm}$, posteroanterior projection with the beam perpendicular to the bed. A dual-channel transmission ionisa- guida metallica sotto controllo ecotomografico, avvalendosi della scopia solo per il controllo durante la dilatazione del palloncino con cui viene eseguita la bilioplastica: in un caso un catetere a palloncino di $6 \mathrm{~mm}$ di diametro, nell'altro caso un cutting baloon di $8 \mathrm{~mm}$ (Fig. 2). Dopo il controllo colangiografico, eseguito con un rapido flash di scopia con parametri ridotti per verificarne l'esito, la procedura è stata terminata sotto controllo ecotomografico; in un caso, rimuovendo il catetere di drenaggio e la guida ed embolizzando il tramite mediante una spirale di Gianturco (Fig. 3). Negli altri due casi per il posizionamento di catetere di drenaggio biliare interno od interno-esterno si è utilizzata la guida ecotomografica ed un rapido flash di scopia al termine della manovra.

Il successo tecnico è stato totale nei casi in esame e non si sono verificate complicanze peri-procedurali, ciò ha permesso di ridurre al minimo il tempo medio di scopia che è stato di 3,7 minuti.

Misurazioni dosimetriche

Oltre a quelle normalmente eseguite nell'ambito del programma di controllo della qualità, per eseguire una affidabile stima preventiva della dose sono state eseguite misure dosimetriche specifiche per la caratterizzazione dell'apparecchio utilizzato. Per valutare l'influenza dei parametri di esposizione selezionabili dall'operatore (tipo di scopia, diametro dell'IB e diaframmatura del campo) sono state effettuate misure simulando le condizioni operative delle procedure, con un fantoccio in plexiglass di $10 \mathrm{~cm}$ di spessore, distanza fuoco ingresso paziente di $75 \mathrm{~cm}$, distanza fuoco IB di $120 \mathrm{~cm}$, proiezione PA con fascio perpendicolare al lettino. Per le misure è stata utilizzata una camera a ionizzazione trasmissiva a doppio canale con misura contemporanea di DAP e kerma in aria puntuale (Diamentor M4KDK, PTW, Freiburg). Nel caso di misure in vivo, oltre alle misure con camera trasmissiva per valutare le dimensioni del fascio all'ingresso sul paziente sono state utilizzate pellicole Kodak X-omat V [9]. Per la valutazione della dose efficace è stato utilizzato il programma di calcolo PCXMC (STUK. radiation and Nuclear Safety Authority, P.O. Box 14, FIN00881 Helsinki, Finlandia), che utilizza il metodo Monte Carlo [10] e tiene in considerazione l'età e le dimensioni reali del paziente.

\section{Risultati}

I risultati delle valutazioni effettuate su fantoccio sono rappresentati nelle Figure 4 e 5 , rispettivamente in termini di dose efficace per minuto e di dose in ingresso superficiale per minuto. Tra le tipologie di scopia, risulta che la pulsata indicata sul tavolo di comando con $i$ due impulsi è quella 


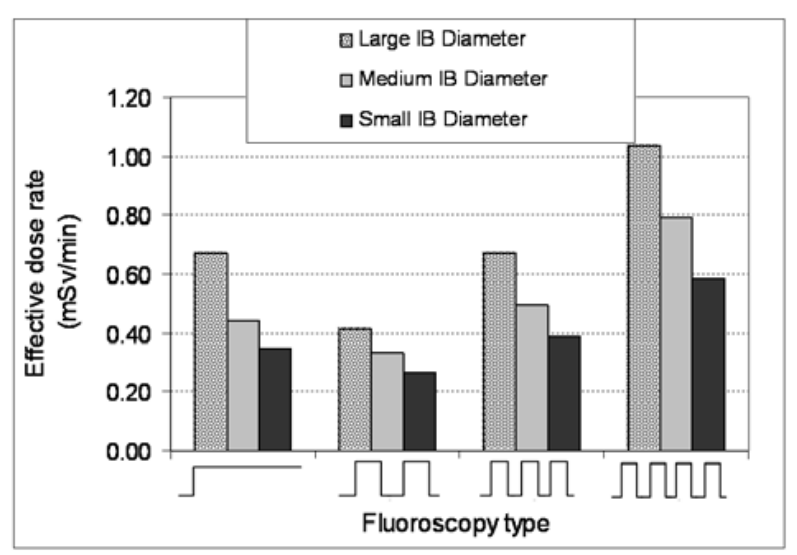

Fig. 4 Effective dose rates per fluoroscopy minute with different image-intensifier diameters (different magnifications) and different fluoroscopy modes.

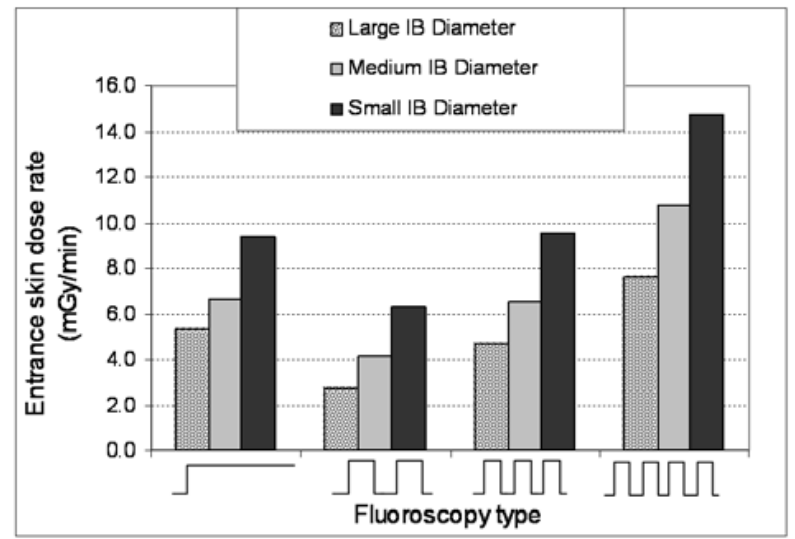

Fig. 5 Entrance skin-dose rates per fluoroscopy minute with different image-intensifier diameters (different magnifications) and different fluoroscopy modes.

tion chamber providing simultaneous measurement of the DAP and air kerma (Diamentor M4KDK, PTW, Freiburg) was used for the measurements. In addition to the transmission chamber measurements, for in vivo measurements, we determined the size of the beam area at the patient entrance using Kodak X-Omat V films [9]. To evaluate the effective dose, we used the PCXMC programme (STUK Radiation and Nuclear Safety Authority, Helsinki, Finland), which is based on the Monte Carlo method [10] and takes into account the age and actual size of the patient.

\section{Results}

Results of the assessments performed on the phantom are shown in Figs. 4 and 5 as effective dose per minute and ESD per minute, respectively. Among fluoroscopy modes, it appears that pulsed fluoroscopy, indicated by two pulses on the operating console, is the technique that imparts the low-

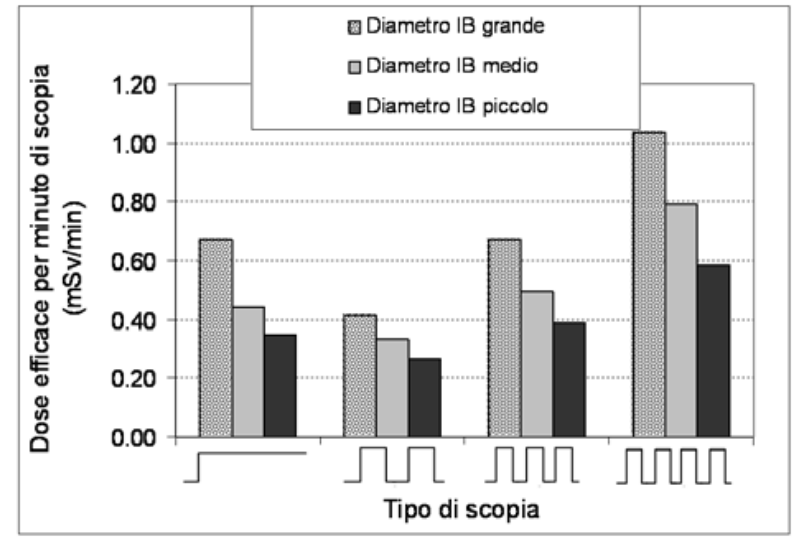

Fig. 4 Valori di dose efficace per minuto di scopia al variare del diametro dell'IB (diversi ingrandimenti dell'immagine) e del tipo di scopia.

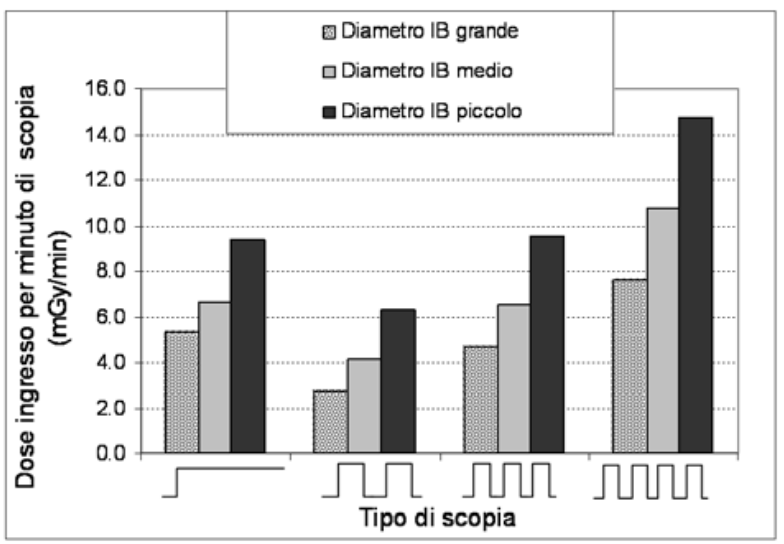

Fig. 5 Valori di dose in ingresso per minuto di scopia al variare del diametro dell'IB (diversi ingrandimenti dell'immagine) e del tipo di scopia.

che minimizza la dose al paziente. La scopia pulsata " $3 \mathrm{im}$ pulsi" e quella continua presentano valori simili di dose, mentre la scopia " 4 impulsi" è quella con $i$ valori maggio$r i$ da utilizzare quindi solo se giustificata dall'esigenza di una qualità di immagine solo con essa ottenibile. Al diminuire del diametro dell'IB (aumento dell'ingrandimento dell'immagine) si ha una diminuzione della dose efficace e un aumento della dose in ingresso. La conoscenza dei ratei di dose permette inoltre una stima preventiva della dose al paziente; infatti ipotizzando delle condizioni di lavoro standard è possibile ottenere la dose moltiplicando il valore dei ratei misurati per il tempo di scopia ipotizzabile.

Le Figg. 6 e 7 mostrano l'influenza dell'uso dei diaframmi sulle due grandezze dosimetriche. Le misure sono state effettuate in 3 condizioni con diaframmatura crescente: con diaframmi appena presenti sui bordi del campo, con diaframmi tali da formare un campo quadrato inscritto nell'area dell'IB e con diaframmi tali da creare un campo quadrato interno all'area IB. Si osserva come la dose in in- 


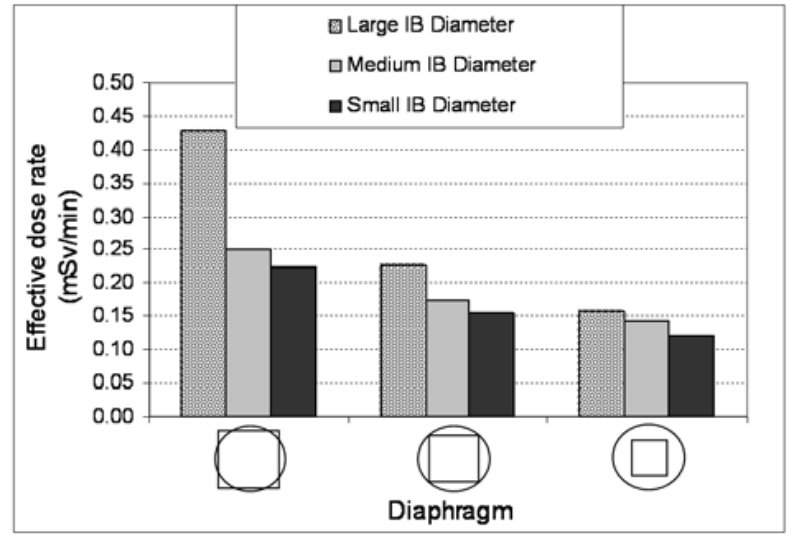

Fig. 6 Effective dose rates per fluoroscopy minute with different image-intensifier diameters (different magnifications) and varying diaphragms obtained with fluoroscopy at two pulses.

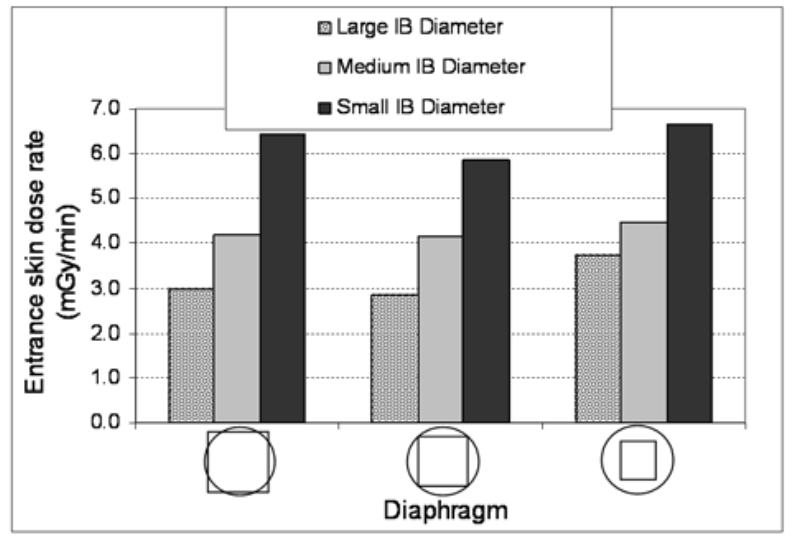

Fig. 7 Entrance skin-dose rates per fluoroscopy minute with different image-intensifier diameters (different magnifications) and varying diaphragms obtained with fluoroscopy at two pulses.

est patient dose. Three-pulse and continuous fluoroscopy have similar dose values, whereas four-pulse fluoroscopy shows the highest values and should be used only when justified by a need for excellent image quality. With decreasing image intensifier diameter (and increasing magnification), the effective dose falls and the entrance dose rises. Knowledge of the dose rates also allows one to predict patient dose: assuming standard working conditions, patient dose can be determined by multiplying the measured dose rates by the expected fluoroscopy time.

Figs. 6 and 7 show the impact of the use of field-limiting diaphragms on the two dosimetric quantities. Measurements were performed in three conditions with increasing limitation of the field: with diaphragms present at the edges of the field only, with diaphragms forming a square field inscribed in the image intensifier area and with diaphragms forming a square field within the image intensifier area. Entrance dose was found to be virtually independent of diaphragm size, whereas effective dose decreased significantly as diaphragm

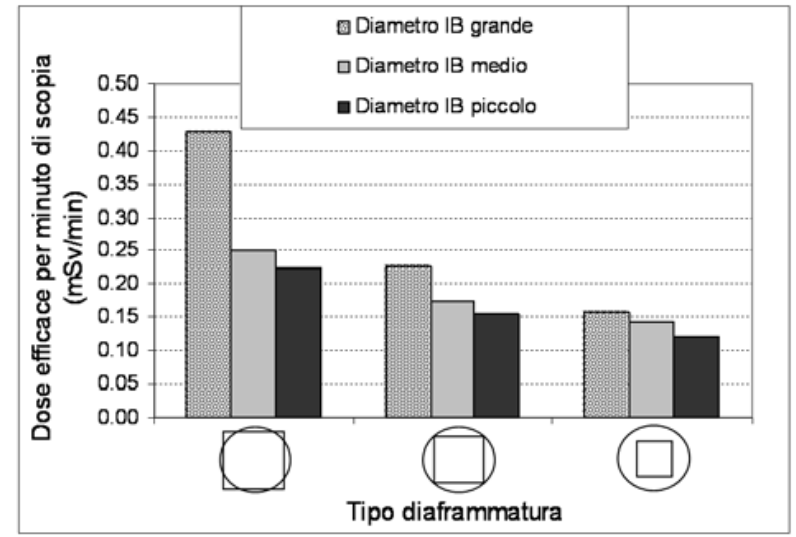

Fig. 6 Valori di dose efficace per minuto di scopia al variare del diametro dell'IB (diversi ingrandimenti dell'immagine) e del tipo di diaframmatura, ottenuti con la scopia di tipo "2 impulsi".

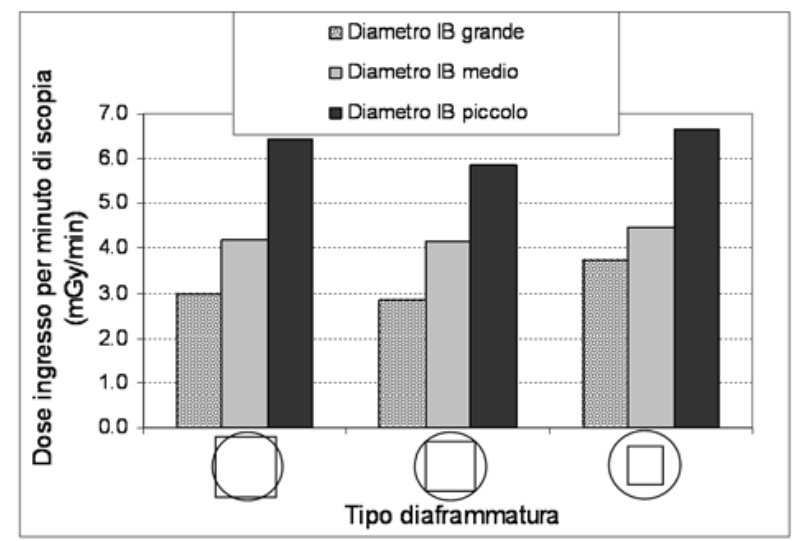

Fig. 7 Valori di dose in ingresso per minuto di scopia al variare del diametro dell'IB (diversi ingrandimenti dell'immagine) e del tipo di diaframmatura, ottenuta con la scopia di tipo 2 impulsi.

gresso risulta praticamente indipendente dalla diaframmatura, mentre la dose efficace si riduce considerevolmente all'aumentare della diaframmatura. I risultati delle misure dosimetriche in vivo ottenuti nelle tre procedure seguite sono quelli mostrati nella Tabella 1.

\section{Discussione}

Dai risultati ottenuti emerge che per il tipo di procedura qui analizzato non sussistono particolari problemi di ordine radioprotezionistico anche per pazienti pediatrici. Infatti $i$ ratei di dose misurati in condizioni di esposizione standard $(<1 \mathrm{mSv} / \mathrm{min}$ per la dose efficace, ordine di grandezza di $10 \mathrm{mGy/min} \mathrm{per} \mathrm{la} \mathrm{dose} \mathrm{d'ingresso} \mathrm{superficiale),}$ tenendo conto che i tempi di esposizione tipici sono di pochi minuti, portano a valori di dose al paziente pienamente accettabili. Tali tempi si riferiscono a procedure tecnicamente ottimali, in cui non si sia verificata alcun tipo di 
Table 1 Exposure parameters and dose values for procedures with in vivo measurements

\begin{tabular}{llllllll}
\hline Procedure & Patient age & $\begin{array}{l}\text { Mean kilovoltage } \\
(\mathrm{kV})\end{array}$ & $\begin{array}{l}\text { Mean current } \\
(\mathrm{mA})\end{array}$ & $\begin{array}{l}\text { Fluoroscopy time } \\
(\mathrm{min})\end{array}$ & $\begin{array}{l}\text { ESD } \\
(\mathrm{mGy})\end{array}$ & $\begin{array}{l}\text { DAP } \\
(\mathrm{Gy} \mathrm{cm})\end{array}$ \\
\hline 1 & 14 months & 67 & 1.5 & 2.6 & 34.6 & $\begin{array}{l}\text { E } \\
(\mathrm{mSv})\end{array}$ \\
2 & $\begin{array}{l}\text { 3 years and } \\
\text { 5 months }\end{array}$ & 70 & 1.7 & 4.3 & 40.6 & 1.5 & 1.94 \\
3 & 3 years & 72 & 1.8 & 4.2 & 50 & 2.3 & 1.2 \\
\hline
\end{tabular}

$E S D$, entrance skin dose; $D A P$, dose-area product; E, effective dose

Tabella 1 Parametri di esposizione e valori di dose per le procedure con misure in vivo

\begin{tabular}{llllllll}
\hline Procedura & Età paziente & $\begin{array}{l}\text { Voltaggio medio } \\
(\mathrm{kV})\end{array}$ & $\begin{array}{l}\text { Corrente media } \\
(\mathrm{mA})\end{array}$ & $\begin{array}{l}\text { Tempo di } \\
\text { fluoroscopia }(\mathrm{min})\end{array}$ & $\begin{array}{l}\text { ESD } \\
(\mathrm{mGy})\end{array}$ & $\begin{array}{l}\text { DAP } \\
\left(\mathrm{Gy} \mathrm{cm}^{2}\right)\end{array}$ \\
\hline 1 & 14 mesi & 67 & 1,5 & 2,6 & 34,6 & 1,5 \\
$(\mathrm{mSv})$ & 40,6 & 1,5 & 0,9 \\
2 & 3 anni e & 70 & 1,7 & 4,3 & 50 & 2,3 & 1,2 \\
\hline
\end{tabular}

$E S D$, dose superficiale in ingresso; DAP, prodotto dose per area; $E$, dose efficace

size increased. The results of the in vivo dosimetric measurements obtained during three procedures are shown in Table 1.

\section{Discussion}

Our results indicate that the kind of procedure considered does not pose particular radiation protection problems, even if performed on children. The dose rates measured under standard exposure conditions $(<1 \mathrm{mSv} / \mathrm{min}$ for the effective dose, in the order of $10 \mathrm{mGy} / \mathrm{min}$ for the ESD), if we consider typical exposure times of only a few minutes, imply perfectly acceptable patient dose values. Typical exposure times refer to technically optimal procedures, with no complications arising during any phase of the procedure (percutaneous puncture of bile ducts, crossing of biliary stenoses, bilioplasty and embolisation of the percutaneous tract) and consequently no need to prolong fluoroscopy time.

As for ESD, comparison with the threshold values for skin injury indicated by the International Commission of Radiation Protection (ICRP) [11] shows that to reach skin doses likely to cause skin injury, exposure time should be at least one order of magnitude higher than is typical for the procedure. Even under the worst possible exposure conditions, the first threshold value of 2,000 mGy is attained only with a fluoroscopy time of $135 \mathrm{~min}$. The choice of optimal exposure parameters must therefore be chiefly aimed at minimising the effective dose. Operatively, it is advisable to complicanza nelle varie fasi intra-, peri- e post-procedurali (puntura percutanea dei dotti biliari, superamento delle stenosi biliari, bilioplastica ed embolizzazione del tramite percutaneo) e che quindi non abbia richiesto un allungamento dei tempi di scopia.

Per quanto riguarda la dose d'ingresso superficiale, una comparazione con i valori soglia indicati dall'International Commission of Radiation Protection (ICRP) [11] in corrispondenza dei quali è possibile l'insorgenza di danni alla cute, mostra che per raggiungere valori di dose alla cute tali da rendere possibili la manifestazione di tali effetti, il tempo di esposizione dovrebbe essere di almeno un ordine di grandezza superiore a quello tipico della procedura. Addirittura nelle peggiori condizioni di esposizione possibili il primo valore soglia di 2000 mGy risulta raggiungibile solo con un tempo di scopia di 135 minuti. La scelta dei parametri di esposizione ottimale deve quindi essere finalizzata principalmente alla minimizzazione della dose efficace. Operativamente è quindi consigliato l'uso di IB piccolo (massimo ingrandimento), che consente contemporaneamente di minimizzare la dose efficace (Figg. 4, 6) e di ottenere la qualità di immagine migliore per le caratteristiche anatomiche del paziente.

Il rateo di dose efficace tipico, anche qui tenendo conto dei tempi tipici di esposizione, fornisce una stima di dose efficace dell'ordine del mSv pari quindi a valori riscontrabili anche in radiodiagnostica. Appare quindi evidente che anche riguardo ai rischi di tipo stocastico la metodica è ac- 
use a small image intensifier (maximum magnification), which allows both minimisation of the effective dose (Figs. $4,6)$ and the best image quality for the patient's anatomical characteristics.

The typical effective dose rate, again assuming typical exposure times, provides an estimate of the effective dose in the order of $1 \mathrm{mSv}$, similar to the values found in radiodiagnostics. It is therefore clear that this method is acceptable for stochastic risks as well. In vivo measurements confirmed estimates derived from measurements on the phantom. The procedures in question show a maximum entrance dose of approximately $50 \mathrm{mGy}$, meaning that an exposure time 40 times greater than needed to reach the first threshold value of 2,000 mGy would be necessary. The likelihood of radiation-induced cancer can be quantified [12] as a factor of $0.013 \% / \mathrm{mSv}$ for boy and of $0.016 \% / \mathrm{mSv}$ for girls under 10 years of age. The effective dose for the two procedures is in the range of $0.9-1.5 \mathrm{mSv}$; hence, the likelihood of malignancy is in the order of a few hundred parts per million.

\section{Conclusions}

In paediatric patients, transhepatic cholangiography followed by percutaneous drainage is the procedure of choice for diagnosing and treating biliary complications of OLT, such as strictures, fistulae or intrahepatic lithiasis. Exposure parameters have been established, for the equipment used and for this kind of procedure, that allow one to obtain the desired image quality with the lowest dose. The measured ESD values allow us to exclude the risk of deterministic skin injury. The stochastic risks were comparable to those found in other radiodiagnostic examinations, and more than 40 procedures would be needed to produce a $1 \%$ likelihood of radiation-induced malignancy.

The dose values obtained show that these interventional procedures, after careful consideration and optimisation of exposure parameters, are acceptable and repeatable, not only on account of their diagnostic and therapeutic value, but also in view of the limited associated risk of deterministic or stochastic effects.

Acknowledgements This work was in part supported by the project "Reduction of the risk associated with exposure to ionising radiation for medical purposes - Compagnia San Paolo di Torino". cettabile. Le misure in vivo eseguite hanno confermato le previsioni ottenute dalle misure su fantoccio. Per le procedure esaminate si ha infatti un valore massimo di dose in ingresso di circa $50 \mathrm{mGy}$, per cui occorrerebbe un tempo di esposizione maggiore di 40 volte rispetto a quello impiegato per arrivare al primo valore soglia di $2000 \mathrm{mGy}$. La probabilità di insorgenza di un tumore letale indotto è quantificabile [12] in un fattore di 0,013\% per mSv per i maschi e di 0,016\% per mSv per le femmine, per soggetti con età inferiore a 10 anni. La dose efficace per le due procedure seguite è compresa nell'intervallo 0,9-1,5 mSv, quindi la probabilità di insorgenza è dell'ordine di alcune centinaia di parti per milione.

\section{Conclusioni}

La colangiografia transepatica seguita dal drenaggio percutaneo rappresenta l'intervento d'elezione nelle complicanze biliari dei pazienti pediatrici sottoposti ad OLT sia dal punto di vista diagnostico sia dal punto di vista terapeutico nel trattamento di stenosi, fistole o litiasi intraepatica. Sono stati stabiliti i parametri di esposizione che consentono di ottenere la qualità di immagine desiderata con la minima dose, per l'apparecchiatura utilizzata e per questa tipologia di procedure. I valori di ESD misurati permettono di escludere il rischio di insorgenza di danni deterministici alla cute. I rischi di tipo stocastico sono risultati paragonabili a valori riscontrati in altre procedure di radiodiagnostica ed inoltre per avere una probabilità di tumore indotto dell'ordine dell'1\% occorrerebbero più di 40 procedure di questo tipo.

I valori di dose ottenuti evidenziano quindi come tali procedure interventistiche, dopo un'attenta analisi dei parametri di esposizione e della loro ottimizzazione, risultino ammissibili e ripetibili non solo per il loro valore diagnostico e terapeutico ma anche in considerazione del limitato rischio correlato di insorgenza di eventi deterministici o stocastici.

Ringraziamenti Lo svolgimento di questo lavoro è stato in parte reso possibile grazie ai finanziamenti provenienti dal progetto "Riduzione del rischio associato all'esposizione a radiazioni ionizzanti per fini medici - Compagnia San Paolo di Torino”. 


\section{References/Bibliografia}

1. Berrocal T, Parron M, Alvarez-Luque A et al (2006) Pediatric liver transplantation: a pictorial essay of early and late complications. Radiographics 26:1187-1209

2. Chang JM, Lee JM, Suh KS et al (2005) Biliary complications in living donor liver transplantation: imaging findings and the roles of interventional procedures. Cardiovasc Intervent Radiol 28:756-767

3. Righi D, Cesarani F, Mauraro E et al (2002) Role of interventional radiology in the treatment of biliary strictures following orthotopic liver transplantation. Cardiovasc Intervent Radiol 25:30-35

4. Righi D, Martina MC, Tola E et al (1990) Percutaneous transhepatic bilioplasty: long term results. Radiol Med 80:492-500
5. Lorenz JM, Funaki B, Leef JA et al (2001) Percutaneous transhepatic cholangiography and biliary drainage in pediatric liver transplant patients. AJR Am J Roentgenol 176:761-765

6. Sunku B, Salvalaggio PRO, Donaldson JS et al (2006) Outcomes and risk factors for failure of radiologic treatment of biliary strictures in pediatric liver transplantation recipients. Liver Transplantation 12:821-826

7. Lorenz JM, Denison G, Funaki B et al (2005) Balloon dilatation of biliaryenteric strictures in children. AJR Am J Roentgenol 184:151-155

8. Belenky A, Mor E, Bartal G et al (2004) Transhepatic ballon dilatation of early biliary strictures in pediatric liver transplantation: successful initial and mid term outcome. Cardiovasc Intervent Radiol 27:491-494
9. Ropolo R, Rampado O, Isoardi P et al (2001) Evaluation of patient doses in interventional radiology. Radiol Med 102:384-390

10. Tapiovaarra M, Lakkisto M, Servomaa A (1997) PCXMC. A PC based Monte Carlo program for calculating patient doses in medical x-ray examinations. Finnish Centre for Radiation and Nuclear Safety, Helsinki, Report No STUKA139

11. ICRP (2001) Avoidance of radiation injuries from medical interventional procedures. ICRP Publication 85

12. ICRP (1990) Recommendations of the international commission on radiological protection. ICRP Publication 60 